\title{
Inventory Control Analysis of Plastic Raw Materials Using Monte Carlo Simulation Approach
}

\section{Analisis Pengendalian Persediaan Bahan Baku Biji Plastik Menggunakan Pendekatan Simulasi Monte Carlo}

\author{
Lusi Mei Cahya Wulandari ${ }^{1}$, Laurensia Dilawati Indrianto P. ${ }^{1}$ \\ ${ }^{1}$ Program Studi Teknik Industri \\ Universitas Katolik Darma Cendika, Jl.Dr.Ir.Soekarno 201, Surabaya 60117 \\ email:lusi.mei@ukdc.ac.id \\ doi: https://doi.org/10.31315/opsi.v14i1.4744
}

Received: $8^{\text {th }}$ May 2021; Revised: $2^{\text {nd }}$ June 2021; Accepted:22 $2^{\text {nd }}$ June 2021;

Available online: $24^{\text {th }}$ June 2021; Published regularly: June 2021

\begin{abstract}
Excess inventory of goods is one of the factors to increase production costs and can reduce the profits earned by the company. The company's ability to control the supply of raw materials is the key to the continuity of the production process. This research was conducted plastic-based packaging industry that focuses on injection and blows molding to determine an inventory control system that can minimize the cost of raw material inventory, especially PET (Polyethylene Terephthalate) type plastic seeds. The inventory model is Economic Order Quantity (EOQ), Economic Order Interval (EOI), and Min-Max. The Monte Carlo simulation approach determines the right inventory model in the future, with Perpetual Inventory Simulation, Periodic Inventory Simulation, and Min-Max Simulation. Based on current demand, the EOQ method produces an economic order quantity of 20,055 kilograms, safety stock 12,687 kilograms, reorder point 53,380 kilograms, with a total inventory cost of Rp 116,237,173. On the other side, the Monte Carlo simulation approach for the next 34 weeks of demand, the EOQ method also produces minimal inventory costs, compared to other models. The EOQ method can be a solution to companies in inventory policies.
\end{abstract}

Keywords: EOQ; EOI; Min-Max; Inventory; Monte Carlo Simulation

\begin{abstract}
ABSTRAK
Persediaan barang yang berlebih menjadi salah satu faktor meningkatnya biaya produksi dan mampu mengurangi keuntungan yang diperoleh perusahaan. Kemampuan perusahaan dalam mengendalikan persediaan bahan baku menjadi kunci keberlangsungan proses produksi. Penelitian ini dilakukan pada industri kemasan berbahan dasar plastik yang berfokus pada injection dan blow moulding dengan tujuan menentukan sistem pengendalian persediaan yang dapat meminimalkan biaya persediaan bahan baku, khususnya biji plastik jenis PET (Polyethylene Terephthalate). Model persediaan yang digunakan adalah Economic Order Qantity (EOQ), Economic Order Interval (EOI) dan Min-Max. Pendekatan simulasi Monte Carlo digunakan untuk menentukan model persediaan yang tepat di masa mendatang, dengan Perpetual Inventory Simulation, Periodic Inventory Simulation dan Min-Max Simulation Berdasarkan permintaan saat ini, metode EOQ menghasilkan jumlah pesanan ekonomis $20.055 \mathrm{~kg}$, safety stock $12.687 \mathrm{~kg}$, reorder point $53.380 \mathrm{~kg}$, dengan total biaya persediaan Rp 116.237.173. Sedangkan pendekatan simulasi Monte Carlo yang dilakukan untuk permintaan 34 minggu mendatang, metode EOQ juga menghasilkan biaya persediaan minimal, dibandingkan metode yang lain. Metode EOQ dapat diajukan kepada perusahaan dalam menetapkan kebijakan persediaan.
\end{abstract}

Kata Kunci: EOQ; EOI; Min-Max; Persediaan; Simulasi Monte Carlo 


\section{PENDAHULUAN}

Persediaaan menjadi salah satu aset penting bagi perusahaan dengan mewakili $50 \%$ dari keseluruhan modal yang diinvestasikan (Heizer, 2011). Sebab itu, manajemen persediaan memiliki peranan vital bagi kelangsungan perusahaan. Dengan memiliki manajemen persediaan yang baik, maka perusahaan dapat mengurangi biaya dengan mengurangi persediaan. Di sisi lain, produksi dapat berhenti dan pelanggan merasa tidak puas ketika sebuah barang tidak tersedia. Sehubungan dengan itu, tujuan manajemen persediaan menjadi penentu keseimbangan antara investasi persediaan dengan pelayanan pelanggan.

Obyek amatan merupakan perusahaan manufaktur yang bergerak di bidang industri kemasan berbahan dasar plastik yang berfokus pada injection dan blow moulding. Produk yang dihasilkan perusahaan di antaranya; pallet plastic blow, keranjang industri, botol plastik, jerigen, galon dan bola pelampung. Dalam menentukan kebijakan persediaan bahan baku, perusahaan mempertimbangkan keputusan bersama dengan pemilik perusahaan. Hasil dari keputusan itu membuat kebijakan untuk menghindari kekurangan persediaan (stockout) guna mengalirkan alur material ke tahap produksi secara lancar sehingga produksi tetap dapat berjalan.

Dalam hal ini, upaya yang dilakukan perusahaan untuk menghindari stockout adalah memesan bahan baku dalam jumlah yang melimpah meski tidak dibutuhkan dalam waktu dekat. Kebijakan itu membawa dampak terjadinya overload sehingga mengganggu jalannya proses produksi. Efek lain dari overload juga turut menyebabkan biaya penyimpanan yang dihasilkan menjadi kian besar yang berpengaruh pada membesarnya total biaya persediaan.

Adanya pengendalian persediaan dengan metode Economic Order Quantity (EOQ) akan menghasilkan biaya yang lebih rendah dari biaya persediaan yang dilakukan perusahaan (Salesti, 2014), (Renta et al., 2013) dan (Lahu et al., 2017). Perhitungan dengan metode EOQ dan Just in Time, memungkinkan perusahaan dapat mengurangi mengurangi total biaya jika dibandingkan dengan sistem manajemen perusahaan yang diterapkan saat ini (Putra, 2015)

Selain itu, metode EOQ dapat menghemat total biaya persediaan menjadi lebih rendah daripada metode persediaan yang telah diterapkan oleh perusahaan dan metode Kanban.

Sumiati (2017) menggunakan metode simulasi pengendalian persediaan Monte Carlo yang menghasilkan total biaya persediaan yang lebih rendah dari total biaya persediaan yang dihasilkan perusahaan. Selain itu, penggunaan metode Monte Carlo mampu membantu perusahaan dalam mengambil keputusan untuk memprediksi persediaan darah di masa datang (Darnis et al., 2020)

Penelitian menggunakan EOQ,POQ (Periodic Order Quantity) dan Min-Max dilakukan oleh Careza et al., (2017) dan Prima Fithri (2014) menghasilkan biaya persediaan EOQ yang paling rendah. Penelitian ini bertujuan untuk menentukan kebijakan pengendalian persediaan menggunakan data yang telah berjalan dengan menggunakan EOQ, EOI dan MinMax, serta menentukan prediksi kebijakan persediaan ke depan dengan pendekatan simulasi menggunakan Perpetual Simulation, Periodic Simulation serta Min-max Simulation

\section{METODE}

Penelitian ini dilaksanakan di perusahaan jerigen plastik yang berlokasi di Rungkut Industri, Surabaya. Penelitian dilakukan selama bulan Maret - Juni 2019 dengan obyek penelitian biji plastik jenis PET (Polyethylen Terephtholate) yang akan diproses menjadi beberapa produk utama.

Adapun dalam penelitian ini menggunakan data yang meliputi:

\subsection{Data Mengenai Pemakaian Bahan Baku}

Data bahan baku tersebut merupakan bahan baku berupa biji plastik PET (Polyethylene Terephthalate) yang nantinya akan menjadi produk botol PET.

Lead time pengiriman biji plastik PET yaitu 1 bulan (4 minggu). Harga bahan baku (biji plastik PET) dari pemasok adalah Rp. 14.791,65,- per $\mathrm{kg}$ (sumber: Bagian Purchasing). 


\subsection{Data Biaya}

Terkait dalam perhitungan pengendalian persediaan data-data biaya yang dibutuhkan ialah:

\subsubsection{Biaya Penyimpanan}

Biaya penyimpanan (holding cost) diperoleh dari perhitungan biaya asuransi bahan baku yang berada di gudang pemakaian (fraksi simpan). Biaya itu kemudian dikalikan dengan harga beli bahan baku per kg. Sebagai catatan, biaya asuransi bahan baku fraksi simpan adalah $3 \%$ per bulan.

$C c=P F$

$P=$ Harga bahan baku

$F=$ Fraksi simpan

$C c=$ Rp. 14.791,65,- per kg x 3\% per bln

Biaya simpan adalah Rp 443,75 per kg per bulan.

\subsubsection{Biaya Pemesanan}

Biaya pemesanan (order cost) diperoleh dari biaya untuk fax atau telepon serta gaji semua operator yang berperan dalam pemesanan bahan baku antara lain operator gudang dan QC. Ongkos pengiriman tidak termasuk dalam biaya pesan karena ongkos tersebut ditanggung oleh supplier.

Biaya pesan $(\mathrm{Co})=$ biaya sekali pesan $\mathrm{x}$ frekuensi pemesanan

Co $=$ Rp. 258.000,-

Selama 8 bulan perusahaan melakukan pemesanan sebanyak 8 kali dengan jumlah pesan $374.000 \mathrm{~kg}$

Tahap pengolahan data meliputi

1. Perhitungan pemesanan yang optimal dengan EOQ,EOI,Min-Max

2. Melakukan distribusi probabilitas demand

3. Simulasi demand dengan Monte Carlo

4. Analisis perhitungan

5. Perbandingan antara kondisi existing dengan hasil simulasi.

\section{HASIL DAN PEMBAHASAN}

Pada bagian ini akan membahas mengenai perhitungan pengendalian persediaan dengan metode EOQ, EOI dan Min-Max menggunakan data-data yang telah terkumpul, periode November 2018-Juni 2019. Selanjutnya akan dilakukan simulasi permintaan menggunakan simulasi Monte Carlo, dengan melakukan generate random number melalui program Microsoft Excel dengan formula $=\operatorname{RAND}()$.
Sebelum simulasi dijalankan, terlebih dahulu dibuat distribusi probabilitas yang diperoleh dari data historis pemakaian biji plastik PET periode November 2018 - Juni 2019.

Tahap simulasi akan dilakukan dengan pendekatan tiga metode sebagai pembanding. Tiga metode tersebut adalah metode EOQ yang menggunakan Perpetual Inventory Simulation, metode EOI yang menggunakan Periodic Inventory Simulation, dan metode Min-Max yang menggunakan Mix-Max Inventory Simulation. Setelah melalui tahap simulasi, data akan dianalisis dengan membandingkan ketiga metode pengendalian persediaan dan analisis hasil perbandingan simulasi. Dengan demikian, akan mendapatkan jumlah pesanan yang dapat meminimalkan total biaya persediaan tahunan.

\subsection{Perhitungan Metode EOQ, EOI, dan Min-Max Inventory}

Data yang telah dikumpulkan akan diolah sesuai dengan metode yang telah ditetapkan. Guna mendapatkan total biaya yang paling minim, maka metode yang akan digunakan dalam perhitungan ini adalah metode EOQ, EOI dan Min-Max. Adapun alasan lain dibalik pemilihan ketiga metode itu adalah kesesuaiannya dengan kondisi perusahaan yang tidak dapat melakukan back order serta tak adanya diskon pada pemesanan bahan baku dalam jumlah tertentu.

Perhitungan Economic Order Quantity (EOQ)

Dalam perhitungan EOQ, menggunakan reorder point (titik pemesanan kembali) untuk pemesanannya. Prinsip dari reorder point adalah pemesanan akan dilakukan jika persediaan telah mencapai reorder point serta kuantitas pemesanan memiliki jumlah yang sama.



Gambar 1. Grafik Pemakaian biji plastik PET 
Dengan melihat data permintaan kebutuhan bahan baku pada gambar 1 adalah data rekapitulasi selama 8 bulan (November 2018 - Juni 2019), maka diperlukan data kebutuhan baku per minggunya yang hasilnya didapat melalui :

$$
\begin{aligned}
& d=\frac{D}{n} \\
& D=\text { demand dalam } \mathrm{kg} \\
& n=\text { periode dalam minggu } \\
& d=\frac{345.893 \mathrm{~kg}}{34 \text { minggu }} \\
& d=10.173,32 \frac{\mathrm{kg}}{\text { minggu }}
\end{aligned}
$$

Setelah data-data yang diperlukan telah terpenuhi, maka nilai EOQ dapat dicari dengan rumus sebagai berikut: (Tersine ,1994)

$Q^{*}=\sqrt{\frac{2 C o D}{\mathrm{Cc}}}$

$Q^{*}=$ jumlah pesanan ekonomis

$Q^{*}=20.055 \mathrm{~kg}$

Kendati jumlah pesanan ekonomis telah diperoleh datanya, tetapi dalam prakteknya jumlah permintaan memiliki sifat yang tidak pasti dan dinamis. Di samping itu, terdapat kemungkinan lain yang dapat terjadi sehingga peluang persediaan habis masih dapat terjadi. Data yang terkumpul sebelumnya menunjukkan bahwa service level yang ditargetkan oleh perusahaan sebesar $95 \%$.

Dengan begitu, hanya 5\% kemungkinan perusahaan kehabisan persediaan bahan baku. Guna mengantisipasi terjadinya kehabisan persediaan, penting untuk mempersiapkan persediaan dalam jumlah tertentu sebagai stok pengaman (safety stock). Sementara itu, dalam menghitung safety stock memerlukan data standar deviasi dari kebutuhan biji plastik PET selama periode 8 bulan terakhir.

Standar deviasi $(s)$ kebutuhan biji plastik PET per minggu :

$$
\begin{aligned}
& s=\sqrt{\frac{\sum(D i-d)^{2}}{C c}} \\
& s=3.844,264 \mathrm{~kg}
\end{aligned}
$$

$$
\begin{aligned}
& \text { Persediaan Pengaman (Safety Stock) } \\
& S S=Z s \sqrt{L} \\
& S S=\text { safety stock dalam kg } \\
& Z s=\text { standard deviasi permintaan } \\
& L=\text { waktu tunggu pesanan dalam } \\
& \text { minggu } \\
& S S=12.686,07 \mathrm{~kg}
\end{aligned}
$$

Jumlah pemesanan (m)

$$
\begin{aligned}
& m=\frac{\mathrm{D}}{Q^{*}} \\
& m=17,25 \sim 17 \text { kali pesanan }
\end{aligned}
$$

Interval antar pemesanan $(\mathrm{T})$

$$
\begin{aligned}
& T=W \times \frac{1}{m} \\
& W=\text { jumlah hari dalam } 8 \text { bulan } \\
& T=14,23 \text { hari }
\end{aligned}
$$

Sedangkan, titik pemesanan kembali (reorder point) dapat ditentukan melalui lead time pemesanan biji plastik PET 4 minggu. Dengan demikian, perhitungan reorder point $(R)$ yang didapat adalah sebagai berikut:

$$
\begin{aligned}
& R=S S+d L \\
& R=53.379,35 \mathrm{~kg} \approx 53.380 \mathrm{~kg}
\end{aligned}
$$

Di samping itu, rata-rata tingkat persediaan (Average Inventory Level) dan Turn Over Ratio (TOR) dapat ditentukan melalui persamaan sebagai berikut:

$$
\begin{gathered}
I=S S+\left(\frac{1}{2} x Q^{*}\right) \\
I=22.713,57 \mathrm{~kg} \\
T O R=\frac{D}{I} \\
T O R=15,23
\end{gathered}
$$

Total biaya persediaan adalah sebagai berikut:

$$
\begin{aligned}
& T C\left(Q^{*}\right)=\frac{D}{Q^{*}} C o+\left(S S+\frac{1}{2} x Q^{*}\right) C C \\
& T C\left(Q^{*}\right)=\operatorname{Rp} 116.237 .173,-
\end{aligned}
$$

\subsection{Perhitungan Economic Order Interval (EOI)}

Perhitungan EOI dengan pemesanan bahan baku memiliki nilai yang seimbang antara interval pemesanan dengan kuantitas pemesanan yang bersifat dinamis sesuai jumlah persediaan yang dimiliki. Dengan data-data tersebut, maka perhitungan EOI dapat dilakukan dengan formulasi sebagai berikut (Fadlillah, 2008):

$$
\begin{aligned}
& T^{*}=\sqrt{\frac{2 C o}{C c D}} \\
& T^{*}=\text { interval pemesanan yang optimal } \\
& T^{*}=0,058
\end{aligned}
$$

Data historis memerlukan penyesuaian perhitungan untuk memberikan kemudahan dalam melakukan inspeksi secara periodik dalam jangka waktu mingguan. Dengan pengambilan data selama jangka waktu 34 minggu, maka perhitungannya menjadi:

$$
T^{*}=0,058 \times 34 \text { minggu }=1,972 \text { minggu }
$$




$$
\sim 2 \text { minggu }
$$

Persediaan dalam jumlah tertentu sebagai stok pengaman (safety stock) menjadi sangat penting dalam upaya menghindari risiko kehabisan bahan baku.

$$
\begin{aligned}
& S S=Z s \sqrt{L+T^{*}} \\
& S S=15.537,2 \mathrm{~kg} \sim 15,538 \mathrm{~kg}
\end{aligned}
$$

Perbedaan perhitungan antara EOI dan EOQ terlihat dari Maximum Inventory Level yang dimiliki oleh EOI, sedangkan EOQ tidak. Maximum Inventory Level merupakan tingkatan maksimum persediaan yang cukup besar dalam memenuhi permintaan selama waktu interval pesanan $\left(T^{*}\right)$ dan lead time $(L)$.

$$
\begin{aligned}
& E=S S+d\left(T^{*}+L\right) \\
& E=76.577,92 \mathrm{~kg} \sim 76.578 \mathrm{~kg}
\end{aligned}
$$

Di satu sisi, rata-rata tingkat persediaan (Average Inventory Level) dan Turn Over Ratio (TOR) dapat diperoleh dari perhitungan:

$$
\begin{aligned}
& I=S S+1 / 2\left(d T^{*}\right) \\
& I=25.711,32 \mathrm{~kg} \\
& \text { TOR }=\frac{D}{I} \\
& \text { TOR }=13,45
\end{aligned}
$$

Kuantitas pesanan untuk periode pesanan dapat dicari sebagai berikut:

$$
\begin{aligned}
& Q=E-I \\
& Q=50.866,68 \mathrm{~kg} \approx 50.867 \mathrm{~kg}
\end{aligned}
$$

Total biaya persediaan dalam 8 bulan (34 minggu) :

$$
\begin{aligned}
& T C\left(T^{*}\right)=\frac{C o}{T^{*}}+\left(S S+\frac{1}{2} x d T^{*}\right) C C \\
& T C\left(T^{*}\right)=\operatorname{Rp} 126.861 .393,-
\end{aligned}
$$

\subsection{Perhitungan Inventory (Min- Max)}

Minimum-Maximum

Reorder menjadi sinyal cara kerja perhitungan Min-Max yang akan muncul dan harus segera dilakukan ketika persediaan telah melewati batas-batas minimum dan mendekati batas safety stock. Dalam artian, batas reorder level juga sebagai stock minimum, sedangkan batas maksimum stok merupakan batas investasi perusahaan dalam bentuk persediaan bahan baku.

Adapun nilai safety stock ditentukan melalui nilai kebutuhan bahan baku (biji plastik PET) setiap minggu yang dapat dilihat dari perhitungan berikut:

$$
\begin{aligned}
& S S=(\text { Pemakaian maksimal }- \\
& \quad \text { ratarata }) x L \\
& S S=20.236,2 \mathrm{~kg} \sim 20.236 \mathrm{~kg}
\end{aligned}
$$

Metode Min-Max memiliki 2 parameter baru yaitu minimum stock yang merupakan titik pemesanan kembali dan maximum stock yang merupakan tingkat persediaan maximum yang diizinkan. Perhitungan Min-Max sebagai berikut:

$$
\begin{aligned}
& \text { Min Stock }=(d L)+S S \\
& \text { Min Stock }=60.928 \mathrm{~kg} \\
& \text { Max Stock }=2(d L)+S S \\
& \text { Max Stock }=101.624 \mathrm{~kg}
\end{aligned}
$$

Menentukan jumlah pesanan dari metode MinMax dihitung dari perbedaan nilai maximum stock dengan minimum stock.

$$
\begin{aligned}
& Q=\text { Max stock }- \text { Min stock } \\
& Q=101.624-60.928 \\
& Q=40.696 \mathrm{~kg}
\end{aligned}
$$

Total pesanan bahan baku $(m)$ yang dilakukan selama 8 bulan dan interval antar pesanan $(T)$ pada metode Min-Max adalah sebagai berikut:

$$
\begin{aligned}
& m=\frac{D}{Q} \\
& m=9 \text { kali pesanan selama } 8 \text { bulan } \\
& T=W \times \frac{1}{m} \\
& W=\text { Jumlah hari dalam } 8 \text { bulan } \\
& T=26 \text { hari }
\end{aligned}
$$

Sedangkan untuk menentukan rata-rata tingkat persediaan (Average Inventory Level) dan Turn Over Ratio (TOR) dapat dihitung dengan:

$$
\begin{gathered}
I=S S+(1 / 2 Q) \\
I=40.584 \mathrm{~kg} \\
T O R=\frac{D}{I} \\
T O R=8,52
\end{gathered}
$$

Total biaya persediaan dalam 8 bulan adalah sebagai berikut:

$$
\begin{aligned}
& T C(\text { Min }- \text { Max })=\frac{D}{Q} C o+C c D \\
& T C(\text { Min-Max })=\operatorname{Rp} 155.682 .872
\end{aligned}
$$

Dari hasil perhitungan ketiga metode pengendalian persediaan, yaitu metode EOQ, metode EOI, dan metode Min-Max mempunyai kelebihan dan kekurangan masing-masing. Hasil perbandingan metode EOQ, metode EOI, dan metode Min-Max terhadap bahan baku biji plastik PET dapat dilihat pada Tabel 1 
Tabel 1.Perbandingan Metode EOQ,EOI dan metode

\begin{tabular}{lrrr}
\multicolumn{4}{c}{ Min-Max } \\
\hline Kriteria & EOQ & EOI & \multicolumn{1}{c}{ Min-Max } \\
\hline Order Quantity (kg) & 20.055 & 50.867 & 40.696 \\
Safety Stock (kg) & 12.687 & 15.538 & 20.236 \\
Inventory Level (kg) & 22.713 & 25.711 & 40.584 \\
Turn Over Ratio & 15,23 & 13,45 & 8,52 \\
Total Inventory Cost & 116.237 .173 & 126.861 .393 & 155.682 .872 \\
(Rp) & & & \\
\hline
\end{tabular}

Perbandingan setiap metode pengendalian persediaan akan dilakukan berdasarkan 5 kriteria yaitu jumlah pesanan (order quantity), persediaan pengaman (safety stock), tingkat persediaan rata-rata (inventory level), rasio pengembalian aset (turn over ratio), dan terakhir yang menjadi tujuan penelitian ini adalah total biaya persediaannya.

Perbandingan yang pertama adalah jumlah pesanan yang dilakukan. Pada metode EOQ jumlah pesanan yang paling optimal yaitu $20.055 \mathrm{~kg}$ setiap pesan, sedangkan dengan metode EOI diperoleh dari pesanan rata-rata yaitu $50.867 \mathrm{~kg}$. Metode Min-Max mempunyai jumlah pesanan $40.696 \mathrm{~kg}$. Metode EOI memiliki jumlah pesanan paling tinggi karena dasar persediaan yang digunakan adalah persediaan maksimum. Perbandingan yang kedua adalah safety stock, dapat terlihat bahwa metode EOI membutuhkan safety stock lebih besar yaitu $15.538 \mathrm{~kg}$ jika dibandingkan dengan metode EOQ yang hanya menyediakan safety stock sebanyak $12.687 \mathrm{~kg}$. Sedangkan metode Min-Max memiliki persediaan pengaman paling besar yaitu $20.236 \mathrm{~kg}$, hal ini disebabkan karena dasar penggunaan bahan baku maksimal cukup tinggi.

Selanjutnya adalah nilai tingkat persediaan. Metode Min-Max memiliki nilai tingkat persediaan yang paling besar dari kedua metode yang lain karena metode ini memiliki nilai safety stock dan order quantity yang cukup besar. Kemudian Turn Over Ratio (TOR), yaitu rasio pengembalian aset atau tolak ukur keberhasilan inventory, maka metode yang mempunyai Turn Over Ratio (TOR) paling besar adalah yang lebih baik. Dapat dilihat pada tabel bahwa metode EOQ adalah yang lebih baik jika dibandingkan dua metode yang lain dengan nilai rasio sebesar 15,23.

Perbandingan yang terakhir adalah besarnya total biaya persediaan selama 34 minggu. Dari ketiga metode pengendalian terlihat bahwa metode EOQ memperoleh total biaya paling rendah

\subsection{Simulasi Persediaan dengan Menggunakan Metode Monte Carlo}

Dengan menggunakan simulasi Monte Carlo dapat memprediksi probabilitas yang terjadi di masa depan. Selain itu, menjadi alat untuk mengantisipasi permintaan yang melonjak. Dengan menggunakan tiga metode sebagai pembanding, yaitu metode EOQ yang menggunakan Perpetual Inventory Simulation, metode EOI yang menggunakan Periodic Inventory Simulation, dan metode Min-Max dengan Min-Max Inventory Simulation.

Dari ketiga metode tersebut memiliki keunggulan dan kelemahan yang sesuai dengan situasi permintaan.

Selama 34 minggu, simulasi dilakukan untuk masing-masing metode. Data-data yang telah terkumpul kemudian dilakukan generate random number melalui program Microsoft Excel dengan formula $=$ RAND(). Data random selanjutnya akan diolah sesuai dengan range nya berdasarkan permintaan masa lalu, sehingga memberikan data simulasi untuk data permintaan yang baru.

Tabel 2. Distribusi Probabilitas Biji Plastik PET

\begin{tabular}{crccl}
\hline $\begin{array}{c}\text { Demand } \\
(\mathrm{kg})\end{array}$ & $\mathrm{F}$ & Probability & $\begin{array}{c}\text { Cumulative } \\
\text { Probability }\end{array}$ & Range Probability \\
\hline 3.501 & 3 & 0,0882 & 0,0882 & 0 \\
5.848 & 2 & 0,0588 & 0,1471 & $0,0883-0,1471$ \\
8.195 & 5 & 0,1471 & 0,2941 & $0,1472-0,2941$ \\
10.542 & 4 & 0,1176 & 0,4118 & $0,2942-0,4118$ \\
12.889 & 13 & 0,3824 & 0,7941 & $0,4119-0,7941$ \\
15.236 & 7 & 0,2059 & 1,0000 & $0,7942-1,0000$ \\
& 34 & & & \\
\hline
\end{tabular}

\subsection{Perpetual Inventory Simulation}

Data unit balance periode 0 menggunakan data aktual rata rata persediaan perusahaan sebesar $48.620 \mathrm{~kg}$. 
Tabel 3. Hasil Simulasi Kebutuhan Bahan Baku dengan EOQ

\begin{tabular}{|c|c|c|c|c|c|c|c|c|}
\hline \multirow{2}{*}{$\begin{array}{c}\text { Simulasi } \\
\text { week }\end{array}$} & \multirow{2}{*}{$\begin{array}{c}\text { Rand } \\
\text { Numbers } \\
\text { Demand }\end{array}$} & \multicolumn{4}{|c|}{ Simulated Activity } & \multicolumn{3}{|c|}{ Simulated Cost (Rp) } \\
\hline & & Demand(kg) & Order(kg) & $\mathrm{m}$ & Unit balance(kg) & $\begin{array}{c}\text { Holding } \\
\text { Cost }\end{array}$ & $\begin{array}{c}\text { Order } \\
\text { Cost }\end{array}$ & $\begin{array}{c}\text { Inventory } \\
\text { Cost }\end{array}$ \\
\hline 0 & & & & & 48620 & & & \\
\hline 1 & 0.3438 & 10542 & 20055 & 1 & 58133 & 6449275 & 258000 & 6707275 \\
\hline 2 & 0.4014 & 10542 & 20055 & 1 & 67646 & 7504647 & 258000 & 7762647 \\
\hline 3 & 0.6634 & 12889 & & & 54757 & 6074742 & & 6074742 \\
\hline 4 & 0.6036 & 12889 & 20055 & 1 & 61923 & 6869738 & 258000 & 7127738 \\
\hline 5 & 0.7525 & 12889 & 20055 & 1 & 69089 & 7664734 & 258000 & 7922734 \\
\hline 6 & 0.0965 & 5848 & & & 63241 & 7015957 & & 7015957 \\
\hline 7 & 0.2824 & 8195 & & & 55046 & 6106803 & & 6106803 \\
\hline 8 & 0.235 & 8195 & 20055 & 1 & 66906 & 7422552 & 258000 & 7680552 \\
\hline 9 & 0.9542 & 15236 & 20055 & 1 & 71725 & 7957172 & 258000 & 8215172 \\
\hline 10 & 0.1927 & 8195 & & & 63530 & 7048018 & & 7048018 \\
\hline 11 & 0.2259 & 8195 & & & 55335 & 6138865 & & 6138865 \\
\hline 12 & 0.9916 & 15236 & 20055 & 1 & 60154 & 6673485 & 258000 & 6931485 \\
\hline 13 & 0.6992 & 12889 & 20055 & 1 & 67320 & 7468481 & 258000 & 7726481 \\
\hline 14 & 0.4722 & 12889 & & & 54431 & 6038575 & & 6038575 \\
\hline 15 & 0.1113 & 5848 & 20055 & 1 & 68638 & 7614700 & 258000 & 7872700 \\
\hline 16 & 0.4048 & 10542 & & & 58096 & 6445170 & & 6445170 \\
\hline 17 & 0.2613 & 8195 & 20055 & 1 & 69956 & 7760919 & 258000 & 8018919 \\
\hline 18 & 0.1098 & 5848 & & & 64108 & 7112142 & & 7112142 \\
\hline 19 & 0.9827 & 15236 & 20055 & 1 & 68927 & 7646761 & 258000 & 7904761 \\
\hline 20 & 0.8288 & 15236 & & & 53691 & 5956480 & & 5956480 \\
\hline 21 & 0.908 & 15236 & 20055 & 1 & 58510 & 6491099 & 258000 & 6749099 \\
\hline 22 & 0.4601 & 12889 & 20055 & 1 & 65676 & 7286095 & 258000 & 7544095 \\
\hline 23 & 0.1456 & 5848 & & & 59828 & 6637318 & & 6637318 \\
\hline 24 & 0.7887 & 12889 & 20055 & 1 & 66994 & 7432314 & 258000 & 7690314 \\
\hline 25 & 0.8631 & 15236 & 20055 & 1 & 71813 & 7966934 & 258000 & 8224934 \\
\hline 26 & 0.912 & 15236 & & & 56577 & 6276652 & & 6276652 \\
\hline 27 & 0.8368 & 15236 & 20055 & 1 & 61396 & 6811272 & 258000 & 7069272 \\
\hline 28 & 0.3486 & 10542 & 20055 & 1 & 70909 & 7866644 & 258000 & 8124644 \\
\hline 29 & 0.8943 & 15236 & & & 55673 & 6176363 & & 6176363 \\
\hline 30 & 0.0575 & 3501 & 20055 & 1 & 72227 & 8012863 & 258000 & 8270863 \\
\hline 31 & 0.8159 & 15236 & & & 56991 & 6322582 & & 6322582 \\
\hline 32 & 0.547 & 12889 & 20055 & 1 & 64157 & 7117578 & 258000 & 7375578 \\
\hline 33 & 0.9705 & 15236 & 20055 & 1 & 68976 & 7652197 & 258000 & 7910197 \\
\hline 34 & 0.5619 & 12889 & & & 56087 & 6222292 & & 6222292 \\
\hline Total & & 393633 & 401100 & 20 & & $2.37 \mathrm{E}+08$ & 5160000 & $2.42 \mathrm{E}+08$ \\
\hline
\end{tabular}

Hasil simulasi metode EOQ (Tabel 3) dengan perpetual inventory simulation dilakukan pesanan sebanyak 20 kali selama 34 minggu. Kemudian total holding cost $\mathrm{Rp}$. 237.241.418,04,- dan total order cost Rp. 5.160.000,- sehingga total inventory cost selama 34 minggu adalah Rp. 242.401.418,04.

\subsection{Periodic Inventory Simulation}

Data on hand (unit balance periode 0) menggunakan rata rata persediaan perusahaan. Pemesanan dilakukan dengan selang waktu 2 minggu dengan jumlah pesanan berubah sesuai dengan kebutuhan. 
Opsi

Vol 14 No 1 June 2021

p-ISSN 1693-2102

e-ISSN 2686-2352

Tabel 4. Hasil Simulasi Kebutuhan Bahan Baku dengan EOI

\begin{tabular}{|c|c|c|c|c|c|c|c|c|}
\hline \multirow{2}{*}{$\begin{array}{l}\text { Simulasi } \\
\text { week }\end{array}$} & \multirow{2}{*}{$\begin{array}{c}\text { Rand } \\
\text { Numbers } \\
\text { Demand }\end{array}$} & \multicolumn{4}{|c|}{ Simulated Activity } & \multicolumn{3}{|c|}{ Simulated Cost (Rp) } \\
\hline & & Demand(kg) & Order(kg) & $\mathrm{m}$ & $\begin{array}{c}\text { Unit } \\
\text { balance }(\mathrm{kg})\end{array}$ & $\begin{array}{c}\text { Holding } \\
\text { Cost }\end{array}$ & $\begin{array}{c}\text { Order } \\
\text { Cost }\end{array}$ & $\begin{array}{c}\text { Inventory } \\
\text { Cost }\end{array}$ \\
\hline 0 & & & & & 48620 & & & \\
\hline 1 & 0.3438 & 10542 & & & 38078 & 4224373 & & 4224373 \\
\hline 2 & 0.4014 & 10542 & 49042 & 1 & 76578 & 8495563 & 258000 & 8753563 \\
\hline 3 & 0.6634 & 12889 & & & 63689 & 7065658 & & 7065658 \\
\hline 4 & 0.6036 & 12889 & 25778 & 1 & 76578 & 8495563 & 258000 & 8753563 \\
\hline 5 & 0.7525 & 12889 & & & 63689 & 7065658 & & 7065658 \\
\hline 6 & 0.0965 & 5848 & 18737 & 1 & 76578 & 8495563 & 258000 & 8753563 \\
\hline 7 & 0.2824 & 8195 & & & 68383 & 7586410 & & 7586410 \\
\hline 8 & 0.235 & 8195 & 16390 & 1 & 76578 & 8495563 & 258000 & 8753563 \\
\hline 9 & 0.9542 & 15236 & & & 61342 & 6805281 & & 6805281 \\
\hline 10 & 0.1927 & 8195 & 23431 & 1 & 76578 & 8495563 & 258000 & 8753563 \\
\hline 11 & 0.2259 & 8195 & & & 68383 & 7586410 & & 7586410 \\
\hline 12 & 0.9916 & 15236 & 23431 & 1 & 76578 & 8495563 & 258000 & 8753563 \\
\hline 13 & 0.6992 & 12889 & & & 63689 & 7065658 & & 7065658 \\
\hline 14 & 0.4722 & 12889 & 25778 & 1 & 76578 & 8495563 & 258000 & 8753563 \\
\hline 15 & 0.1113 & 5848 & & & 70730 & 7846786 & & 7846786 \\
\hline 16 & 0.4048 & 10542 & 16390 & 1 & 76578 & 8495563 & 258000 & 8753563 \\
\hline 17 & 0.2613 & 8195 & & & 68383 & 7586410 & & 7586410 \\
\hline 18 & 0.1098 & 5848 & 14043 & 1 & 76578 & 8495563 & 258000 & 8753563 \\
\hline 19 & 0.9827 & 15236 & & & 61342 & 6805281 & & 6805281 \\
\hline 20 & 0.8288 & 15236 & 30472 & 1 & 76578 & 8495563 & 258000 & 8753563 \\
\hline 21 & 0.908 & 15236 & & & 61342 & 6805281 & & 6805281 \\
\hline 22 & 0.4601 & 12889 & 28125 & 1 & 76578 & 8495563 & 258000 & 8753563 \\
\hline 23 & 0.1456 & 5848 & & & 70730 & 7846786 & & 7846786 \\
\hline 24 & 0.7887 & 12889 & 18737 & 1 & 76578 & 8495563 & 258000 & 8753563 \\
\hline 25 & 0.8631 & 15236 & & & 61342 & 6805281 & & 6805281 \\
\hline 26 & 0.912 & 15236 & 30472 & 1 & 76578 & 8495563 & 258000 & 8753563 \\
\hline 27 & 0.8368 & 15236 & & & 61342 & 6805281 & & 6805281 \\
\hline 28 & 0.3486 & 10542 & 25778 & 1 & 76578 & 8495563 & 258000 & 8753563 \\
\hline 29 & 0.8943 & 15236 & & & 61342 & 6805281 & & 6805281 \\
\hline 30 & 0.0575 & 3501 & 18737 & 1 & 76578 & 8495563 & 258000 & 8753563 \\
\hline 31 & 0.8159 & 15236 & & & 61342 & 6805281 & & 6805281 \\
\hline 32 & 0.547 & 12889 & 28125 & 1 & 76578 & 8495563 & 258000 & 8753563 \\
\hline 33 & 0.9705 & 15236 & & & 61342 & 6805281 & & 6805281 \\
\hline 34 & 0.5619 & 12889 & 28125 & 1 & 76578 & 8495563 & 258000 & 8753563 \\
\hline Total & & 393633 & 421591 & 17 & & $2.63 \mathrm{E}+08$ & 4386000 & $2.67 \mathrm{E}+08$ \\
\hline
\end{tabular}

Dari tabel 4. hasil simulasi metode EOI dengan periodic inventory simulation dilakukan pesanan sebanyak 17 kali selama 34 minggu. Kemudian total holding cost Rp. 262.740.977,04,- dan total order cost Rp. 4.386.000,- sehingga total inventory cost selama 34 minggu adalah Rp. 267.126.977,04.

\subsection{Min-Max Inventory Simulation}

Data on hand (unit balance periode 0) menggunakan persediaan sebesar $48620 \mathrm{~kg}$. dimana setiap kali melakukan pesanan jumlahnya tetap yaitu 40.696 dengan tetap menjaga persediaan minimal. 
Tabel 5. Hasil Simulasi Kebutuhan Bahan Baku dengan Min-Max

\begin{tabular}{|c|c|c|c|c|c|c|c|c|}
\hline \multirow{2}{*}{$\begin{array}{l}\text { Simulasi } \\
\text { week }\end{array}$} & \multirow{2}{*}{$\begin{array}{l}\text { Rand } \\
\text { Numbers } \\
\text { Demand }\end{array}$} & \multicolumn{4}{|c|}{ Simulated Activity } & \multicolumn{3}{|c|}{ Simulated Cost (Rp) } \\
\hline & & Demand(kg) & Order(kg) & $\mathrm{m}$ & $\begin{array}{l}\text { Unit } \\
\text { balance }(\mathrm{kg})\end{array}$ & $\begin{array}{l}\text { Holding } \\
\text { Cost }\end{array}$ & $\begin{array}{l}\text { Order } \\
\text { Cost }\end{array}$ & $\begin{array}{l}\text { Inventory } \\
\text { Cost }\end{array}$ \\
\hline 0 & & & & & 48620 & & & \\
\hline 1 & 0.3438 & 10542 & 40696 & 1 & 78774 & 8739188 & 258000 & 8997188 \\
\hline 2 & 0.4014 & 10542 & & & 68232 & 7569658 & & 7569658 \\
\hline 3 & 0.6634 & 12889 & 40696 & 1 & 96039 & 10654567 & 258000 & 10912567 \\
\hline 4 & 0.6036 & 12889 & & & 83150 & 9224661 & & 9224661 \\
\hline 5 & 0.7525 & 12889 & & & 70261 & 7794755 & & 7794755 \\
\hline 6 & 0.0965 & 5848 & & & 64413 & 7145978 & & 7145978 \\
\hline 7 & 0.2824 & 8195 & 40696 & 1 & 96914 & 10751639 & 258000 & 11009639 \\
\hline 8 & 0.235 & 8195 & & & 88719 & 9842486 & & 9842486 \\
\hline 9 & 0.9542 & 15236 & & & 73483 & 8152204 & & 8152204 \\
\hline 10 & 0.1927 & 8195 & & & 65288 & 7243051 & & 7243051 \\
\hline 11 & 0.2259 & 8195 & 40696 & 1 & 97789 & 10848712 & 258000 & 11106712 \\
\hline 12 & 0.9916 & 15236 & & & 82553 & 9158430 & & 9158430 \\
\hline 13 & 0.6992 & 12889 & & & 69664 & 7728524 & & 7728524 \\
\hline 14 & 0.4722 & 12889 & 40696 & 1 & 97471 & 10813433 & 258000 & 11071433 \\
\hline 15 & 0.1113 & 5848 & & & 91623 & 10164656 & & 10164656 \\
\hline 16 & 0.4048 & 10542 & & & 81081 & 8995126 & & 8995126 \\
\hline 17 & 0.2613 & 8195 & & & 72886 & 8085973 & & 8085973 \\
\hline 18 & 0.1098 & 5848 & & & 67038 & 7437196 & & 7437196 \\
\hline 19 & 0.9827 & 15236 & 40696 & 1 & 92498 & 10261728 & 258000 & 10519728 \\
\hline 20 & 0.8288 & 15236 & & & 77262 & 8571446 & & 8571446 \\
\hline 21 & 0.908 & 15236 & & & 62026 & 6881164 & & 6881164 \\
\hline 22 & 0.4601 & 12889 & 40696 & 1 & 89833 & 9966073 & 258000 & 10224073 \\
\hline 23 & 0.1456 & 5848 & & & 83985 & 9317296 & & 9317296 \\
\hline 24 & 0.7887 & 12889 & & & 71096 & 7887390 & & 7887390 \\
\hline 25 & 0.8631 & 15236 & 40696 & 1 & 96556 & 10711923 & 258000 & 10969923 \\
\hline 26 & 0.912 & 15236 & & & 81320 & 9021641 & & 9021641 \\
\hline 27 & 0.8368 & 15236 & & & 66084 & 7331359 & & 7331359 \\
\hline 28 & 0.3486 & 10542 & 40696 & 1 & 96238 & 10676644 & 258000 & 10934644 \\
\hline 29 & 0.8943 & 15236 & & & 81002 & 8986362 & & 8986362 \\
\hline 30 & 0.0575 & 3501 & & & 77501 & 8597961 & & 8597961 \\
\hline 31 & 0.8159 & 15236 & & & 62265 & 6907679 & & 6907679 \\
\hline 32 & 0.547 & 12889 & 40696 & 1 & 90072 & 9992588 & 258000 & 10250588 \\
\hline 33 & 0.9705 & 15236 & & & 74836 & 8302306 & & 8302306 \\
\hline 34 & 0.5619 & 12889 & & & 61947 & 6872400 & & 6872400 \\
\hline Total & & 393633 & & 10 & & $3.01 \mathrm{E}+08$ & 2580000 & $3.03 \mathrm{E}+08$ \\
\hline
\end{tabular}

Hasil simulasi metode Min-Max dengan Min-Max inventory simulation dapat dilihat pada tabel 5, dilakukan pesanan sebanyak 10 kali selama 34 minggu. Hal ini disebabkan persediaan di tangan adalah maximum stock.

Total holding cost adalah 300.636.195,06,dan total order cost Rp. 2.580.000,- sehingga total inventory cost selama 34 minggu adalah Rp. 303.216.195,06.

\subsection{Analisis Perbandingan}

Pada perpetual inventory simulation menggunakan reorder point dalam penentuan melakukan pesanan, periodic inventory simulation menggunakan interval secara 
periodik dalam penentuan melakukan pesanan, min-max inventory simulation menggunakan minimum stock dalam penentuan melakukan pesanan.

Terdapat perbedaan berapa kali dilakukan pemesanan selama 34 minggu, dapat dilihat pada tabel perpetual inventory simulation melakukan pesanan sebanyak 20 kali, pada tabel periodic inventory simulation melakukan pesanan sebanyak $17 \mathrm{kali}$, dan pada tabel minmax inventory simulation dilakukan pemesanan sebanyak 10 kali dengan jumlah pemesanan yang lebih besar untuk menjaga stok persediaan.

Perbandingan Total Biaya Persediaan dengan demand saat ini dan simulasi, seperti pada tabel 6 .

Tabel 6. Perbandingan biaya persediaan

\begin{tabular}{rccl}
\hline & EOQ & EOI & MinMax \\
Demand & 116.237 .173 & 126.861 .393 & 155.682 .872 \\
saat ini & & & \\
Simulasi & 242.401 .418 & 267.126 .977 & 303.216 .195 \\
\hline
\end{tabular}

Dari segi biaya pesan, perpetual inventory simulation melakukan pesanan paling banyak, maka total order cost-nya menjadi yang paling besar yaitu Rp. 5.160.000,-. Sedangkan total order cost yang paling kecil adalah min-max inventory simulation yaitu Rp. 2.580.000,dengan jumlah pemesanan 10 kali.

Untuk biaya simpan yang paling besar adalah min-max inventori simulation yaitu $\mathrm{Rp}$. 300.636.195,-, hal ini disebabkan menjaga persediaan minimal sebesar $60.928 \mathrm{~kg}$. Sedang biaya simpan minimal dengan menggunakan kuantitas pesan tetap sebesar $20.055 \mathrm{~kg}$.

Perbandingan total biaya persediaannya, hasil dari ketiga metode tersebut baik perhitungan sesuai demand saat ini maupun simulasi metode EOQ yang menghasilkan total biaya persediaan yang paling minimum, kemudian diikuti oleh metode EOI dan metode min-max inventory.

Perbandingan total biaya persediaannya, hasil dari ketiga metode tersebut baik perhitungan sesuai demand maupun simulasi metode EOQ yang menghasilkan total biaya persediaan yang paling minimum, kemudian diikuti oleh metode EOI dan metode min-max inventory. Hal tersebut menunjukkan metode
EOQ adalah metode yang lebih baik daripada metode EOI dan metode Min-Max.

\section{KESIMPULAN}

Ketiga metode yang telah dibandingkan menunjukkan bahwa metode EOQ mampu menghasilkan biaya persediaan terendah, baik untuk demand saat ini maupun yang akan datang. Atas dasar tersebut, metode EOQ dapat menjadi salah satu usulan dalam menentukan kebijakan persediaan bahan baku yang akan ditetapkan oleh pemilik perusahaan .

\section{DAFTAR PUSTAKA}

Careza, R., Sudarso, Y., \& Sadriatwati, S. E. (2017). Analisis Perbandingan Metode EOQ dan Metode POQ Dengan Metode Min-Max Dalam Pengendalian Persediaan Bahan Baku Pada PT Sidomuncul Pupuk Nusantara. Admisi Dan Bisnis, l(ISSN 1411 - 4321), 1122.

Darnis, R., Nurcahyo, G. W., \& Yunus, Y. (2020). Simulasi Monte Carlo untuk Memprediksi Persediaan Darah. Jurnal Informasi Dan Teknologi, 2(2019), 4-9. https://doi.org/10.37034/jidt.v2i4.98

Fadlillah, S. N. (2008). Metode Pengendalian Persediaan Bahan Baku Crude Coconut Oil Yang Optimal Pada Pt. Pse. Industrial and Systems Engineering Assessment Journal (INASEA) - 9(2), 139-153.

Heizer, J. dan B. R. (2011). Operations Management, 10th edition by Jay Heizer, Barry Render (z-lib.org).pdf (10th ed.). Pearson.

Lahu, E. P., Sumarauw, J. S. B., Ekonomi, F., Manajemen, J., Sam, U., Manado, R., \& Belakang, L. (2017). Analisis Pengendalian Persediaan Bahan Baku Guna Meminimalkan Biaya Persediaan Pada Dunkin Donuts Manado. Jurnal EMBA: Jurnal Riset Ekonomi, Manajemen, Bisnis Dan Akuntansi, 5(3), 4175-4184. https://doi.org/10.35794/emba.v5i3.1839 4

Prima Fithri, A. S. (2014). Pengendalian Persediaan Pozzolan di PT.SEMEN PADANG. Jurnal Optimasi Sistem Industri, 13(2), 665-686. 
https://doi.org/10.31334/logistik.v3i2.61 5

Putra, A. . (2015). Analisis Penerapan Manajemen Persediaan pada Perusahaan Goodwill. Jurnal Aplikasi Manajemen, 13(3), 423-434.

Renta, N., Djoko, H., \& Nurseto, S. (2013). Analisis Pengendalian Persediaan Bahan Baku Rokok Pada Pt . Gentong Gotri Semarang Guna Meningkatkan Efisiensi Biaya Persediaan. Journal of Social and Politic, 2(4), 1-8. https://ejournal3.undip.ac.id/index.php/ji $\mathrm{ab} /$ article/view/3478/3408
Salesti, J. (2014). Analisa Penerapan Metode Economic Order Quantity pada Persediaan bahan Baku: Studi Kasus PT.IMECO BATAM TUBULAR. Measurement, 8(3), 21-31.

Sumiati, \& Iriani. (2017). Pengendalian Persediaan Bahan Baku Dengan Menggunakan Simulasi Monte Carlo Di Ud. Selebriti. Tekmapro: Journal of Industrial Engineering and Management, 12(02), 43-55.

Tersine, Richard J.. 1994. Principles of Inventory and Materials Managemen. Fourth Edition. New Jersey: Prentice Hall, Inc. 